\title{
Leadership Style of Transformational Key User in the Success of the Implementation of Enterprise Resource Planning in the Universities in East Java, Indonesia \\ Heri Wijayanto ${ }^{1}$, Tulus Haryono ${ }^{2}$
}

Faculty of Economics, Universitas Muhammadiyah Ponorogo, Jawa Timur, Indonesia ${ }^{1}$

Faculty of Economics and Business, Universitas Sebelas Maret Surakarta, Indonesia ${ }^{2}$

\begin{abstract}
This study is aimed to analyze to what extend is the implementation of Enterprise Resource Planning (ERP) by involving transformational key user leadership style as the moderating variable. This study used DeLone and McLean information system success model approach. There are 285 universities in east Java, Indonesia as the population. As for this study, 164 universities are chosen as the samples by using the disproportionate stratified random sampling through organizational unit analysis. The instrument that is used to analyze the data is Structural equation Modeling (SEM) program Amos 22. The constructs used to make the model are transformational key user leadership, System Quality, and User Satisfaction. The result showed that the quality system has no influence towards the user satisfaction, and transformational key user leadership style moderates the quality system influences the quality system on the user satisfaction.
\end{abstract}

Keywords: Transformational leadership; key user; ERP

\section{Introduction}

Enterprise Resource Planning (ERP) is a multi-module and business solution application that allows the organization to integrate the business work with the company work, data distribution, and source management, also facilitates the access of information in real (Hau \& Kuzic, 2010). ERP is a computerbased system that is designed to process company transaction and facilitates integrated planning and realtime (O’Leary, 2000) .

ERP in universities has its own design, features, content, and database planning that has been adapted so that it suit universities' financial needs and capability by using the service from programmer consultant and other experts. The implementation of ERP has become a demand in some universities. Therefore, an investment in the field of information technology can be set as the development priority in order to increase the universities' competitiveness, to give better service, and to guarantee a wide access with a well-formed blueprint.

In fact, the implementation of ERP does not always run as it was expected. Many companies have spent lots amount of money to implement the ERP system. However, they did not get an optimal result and benefit from that implementation or it is called as information technology paradox. The implementation does not give optimal result and benefit because there is rejection from the user. Besides, the companies are incapable to decide the changes of the design and structure of organization to be suit with the technology that has been selected before (Ethie \& Madsen, 2007).

Broadly speaking, the users do not want to apply the ERP system because they do not want to be equipped with something new and unfamiliar things. In fact, learning something new is a requirement to compete or succeed the business competitiveness and to keep the sustainability of the company (Baheshti, 2006).

Transformational leadership is a leadership style that transform the values that rae believed by his/ her subordinate to support the vision and goal of the organization. By transforming the values, it is expected that there will be a good relationship among the members of the organization, so they can build strong belief towards each others. According to Avolio et al (in Stone, et al., 2004), the characteristics of transformational leadership are charismatic, inspirational, intellectual stimulant, and considerated indivisual. Those characteristics are the things that support an organization member in accepting new system.

\footnotetext{
1 ok_coi@yahoo.com

2 tulusharyono@fe.uns.ac.id
} 
Transformational leadership style is an important thing in the implementation of information system. This is the feature that should be owned by the key user to get the organizational net benefit in form of the improvement of company work, or the individual net benefit in form of the behavior changes that support the company work.

Umble, Haft (2003) stated that the success of the implementation of the information system requires strong leadership, strong commitment, and support from the top management. Moreover, Mandal and Gunasekaran (2003) also stated that the implementation of information system requires strong leadership, well-planned implementation plan, and well-formed financial consideration.

In this case, leadership style can be explained as attitude and action performed by a leader in working with his/ her sub-ordinates, ruling an operational system, doing and overwatching the policy, and resolving internal and external problem (Bass, Bernard \& Riggio, 2006). Key users play an important role in the implementation of ERP because they will act as the trainer, educator, advisor, help-desk recources, and agents of end user (Shehab \& Sharp, 2007). In some cases, the problem encounter by the companies that are succesful or fail in implementing the ERP is around the key users. Key users, broadly spekaing, have strong influence in an organization as well as in the company's sustainability (Bycio \& Hackett, 1995).

\section{Literature Review Definition of ERP}

ERP is a system that integrates some bussiness activities such as human resources, marketing, production, management and customer relationship, and financial matter in a company into a single system by using share database (Wey, et al., 2009). The system of ERP can create a consistency and trnasparency information in a company, so it can improve the eficiency of bussiness process. Besides, it can improve the company's competitiveness.

Generally, ERP executes and integrates the functions of a company and its global problems into one system. There are some problems that usually can be solved by the ERP. They are payroll/ employees cost accounting, general ladger, job/ project management, budgeting, logistic, material, etc. (Subba, 2000).

The implementation of ERP has some purposes. They are; 1) improving the customer service; 2) improving the productivity; 3 ) reducing the cost and inventory turnover; and 4) managing the supply chain and e-commerce. Those purposes can be achieved by developing a good plan and schedule, so the requirements of the resources, labor, material, machines, and financial can be provided adequately and proportionally (Wallace \& Kremzar, 2001).

Furthermore, Leon (2005) explained that there are several benefits that can be taken by the company from the implementation of ERP system. They are lead-time reduction, on-time delivery, time cycle reduction, customer satisfactory improvemnet, supplier's work improvement, flexibility improvement, quality cost reduction, recources improvement, and improvement of informattion accuracy and decision maker ability.

\section{The Success Model of the ERP Implementation}

In the implementation of ERP, there are several models that can be used to measure the success of ERP. One of them is DeLone and McLean Model. This model is developed based on the previous studies conducted by Shannon and Weaver (1949), and Moson (1978). In this case, Shanon \& Waver (1949) categorized the proses of information into three stages. They are:

a. Technical Level. This level is defined as the accuracy and the efficiency of a system that can produce information.

b. This level is defined as the completeness of information in relying the message.

c. Effectiveness Level. This level is defined as the effect of the information to the receiver.

Mason (1978) introduced a theory that is called as Information Influence Theory. This theory emphasizes in the influence of the information and replaces the term effectiveness. Furthermore, influence level is defined as the stages of the occasions that occur at the last moment of information system receiver.

The referred level is receipt, the evaluation from the information and application from the information which is lead to the influence on recipient and the influence on system. The contribution from previous studies and the impact of role changes and the developed information system handling, DeLone dan Mclean (1992) update their model and call it as Updated DeLone and McLean Information System Success Model. This model reflects the dependence from six measurement of information system success: system quality, information quality, service quality, use, user satisfaction, and net benefit. 


\section{Transformational Leadership}

Leadership is defined as the capability to persuade the other's behavior in a particular situation (Hughes, Ginnett, \& Curphy, 1993). Leadership is also referred to an effort to influence people between individuals (interpersonal), through a process of communication to achieve one or more objectives (Gibson \& Donnely, 1987).

Bass (1990) assumes that a better leadership work performance will be done if the leaders are able to do one or more from these four ways:

a. Giving a deeper insight and awareness toward the mission, rising a great sense of pride, and developing a good respect and trust to the employees (Idealized Influence-charisma).

b. Developing a high expectation by using various symbols to focus on the efforts and communicating important goals by using simple methods (Inspirational Motivation).

c. Improving the intelligance, rationality, and an accurate problem-solving (Intellectual Stimulation).

d. Giving attention, guidance, supervision, and training each person individually and personally (Individualized Consideration). This leader will be considered by his or her co-workers and employees as an effective and satisfying leader.

Transformational leadership reflects modern leadership style, so in the implementation of ERP which is the $20^{\text {th }}$ century modern and sophisticated system, is so appropriate and suitable when leadership model uses transformational leadership (Gill et al., 2010).

\section{Key Users}

The implementation processes of ERP in the companies are: the company organization management chooses and decides some individuals who have a full responsibility toward the preparation and the finishing of ERP by using company management instruction. Key user relates to business process and it has more knowledge in its working area, and generally, it is department manager (Taylor, Todd, \& Peter, 1995).

Key user group is established and assigned to estimate the potential of ERP use, when measuring the success of ERP implementation, which is appropriate with company needs. Key user should help to determine proper consultants and work together with them to seek other needs in preparing the implementation of ERP (Gyampah \& Kwasi A., 2004).

Key user will develop the required necessities in the last system, which is needed by end user. In addition, key user will specialize parts of ERP system and becomes a trainer, an educator, an advisor, a help-desk resource and an agent for end user. End user only has knowledge specification from parts on the system where the end user needs to do. Therefore, key user's role is so significant to succeed the last system (Spathis \& Constantinedes, 2003).

The implementation stage is where consultant is on the key user instruction because the system is a configuration package of information system. Customization usually includes a strong relationship between key user and consultant. Key user adjusts process business of the company by applying ERP custom software, and directing end user to provide required data (Gyampah \& Kwasi A, 2004).

\section{Developing Hypothesis}

DeLone and McLean theory stated that the information system is succeed if the system quality improves, thus user satisfaction will improve. This theory test result also shows various results, some researchers support and some do not. The summary of previous study result has been described in the table 1.

Table 1. The summary of previous study result relationship system quality to user satisfaction

\begin{tabular}{llll}
\hline No & \multicolumn{1}{c}{ Author } & \multicolumn{1}{c}{ Object } & \multicolumn{1}{c}{ Result } \\
\hline 1. & Premkumar \& King (1994) & Manufacture (India) & Not supported \\
\hline 2. & McGill et al. (2003) & Universities MBA (Australia) & supported \\
\hline 3. & Urbach, Smonik \& Riemp (2010) & Manufacture (German) & supported \\
& & & \\
\hline 4. & Khayun \& Ractham (2011) & Manufacture (Thailand) & Not supported \\
\hline 5. & Kim \& Lee (2014) & $\begin{array}{l}\text { Implementation ERP di Korea } \\
\text { Telecommunication (Korea) }\end{array}$ & supported \\
\hline
\end{tabular}


Inconsistent previous research of system quality impact on user satisfaction shows that there is another variable, which takes part to strengthen and weaken the impact. Baheshti (2006) states that management support can give guarantee the continuity of the ERP system. Management supports are: involved directly in facing user's difficulties and taking strategic steps to improve the capability of system use, so the user will find it helpful to the system, and then finally will have satisfied feeling.

Transformational leadership style of key user is notified by some activities: help the employees to understand ERP system, which is implemented by the company and train them to be ready and able to use the system.

The capability of the employees using ERP system will help them to do their responsibilities given by the company. In the other hand, the implementation of ERP system will help their job.

This will bring satisfaction feeling from the employees. Based on the description above, this study proposes a research model as defined in the figure 1, and the hypothesis is:

H1: System quality influences on user satisfaction,

H2: Key user transformational leadership moderates the influence of system quality on ERP user satisfaction.

\section{Methodology}

There are 285 universities in east Java, Indonesia as the population. As for this study, 164 universities are chosen as the samples by using the disproportionate stratified random sampling through organizational unit analysis. The instrument that is used to analyze the data is Structural equation Modeling (SEM) program Amos 22. The constructs used to make the model are transformational key user leadership, System Quality, and User Satisfaction.

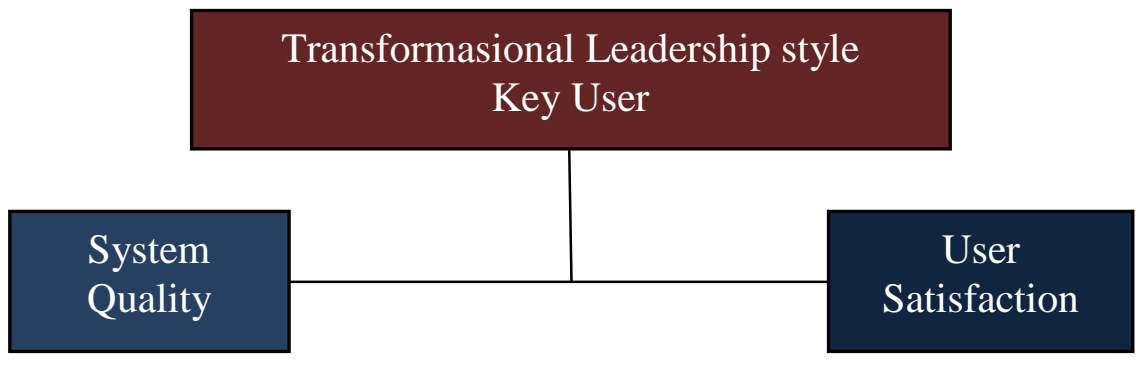

Picture 1. Research Model

\section{Result and Discussion}

Mean score of the highest respondent answer is 3,62 for the question: ERP system is easy to access, and the lowest score is 3,34 for the first question: ERP system is easy to do. This shows that the level of easiness in ERP operation is the challenge of some users. The difficulty of ERP operation can be solved by implementing directory assistance, and structured and arranged training to users. ERP consists of some moduls and each modul has different function and content, which are integrated one another. Therefore, a particular training is needed for each modul according to the main duties and functions of the employees.

Based on the level of difficulties on ERP operation, so the policies of employees job rotation should be done according to the duties and qualification of each employee with a longer time compared with another division. Certification of information systems management expertise from The National Professional Certification Board or Badan Nasional Sertifikasi Profesi (BNSP) requires to do for infomation technology employees.

The lowest score of average respondents' answer is 3,55, telling the benefits of ERP system to others. If the perception of ERP system is good, they tend to be satisfied to use that system and will tell to others. The highest mean score is 3,66 for the question: user feels satisfied toward the whole working results. ERP gives easiness for data sharing, realtime, and helps decision taking. This easiness is experienced by the ERP user of universities in East Java as the whole satisfiying result achievement.

System quality effects on the user satisfaction toward the ERP implementation. Parameter estimation for testing hypotheses is seen from the CR and $p$ value. The CR test results obtained a value of 1.638 or under \pm 1.96 means that the quality system is not positively affect toward the user satisfaction, while the test of the $p$ value obtained value of 0.101 or above 0.05 means that the quality system has no significant effect toward the user satisfaction. 
The test result of the hypothesis indicates that the system quality is not influence positively and significantly impact toward the user satisfaction in the ERP implementation, it means that with the better system quality does not affect to the ERP user satisfaction, this is possible due to the increasing of the system quality which will be accompanied by changes in features or menu in the new ERP, so users have to learn more, and make adjustments to the new system. The Improvement of the quality of quality system has also resulted in the increasing complexity of the work.

The difference result shows that with the better system quality does not improve toward the user satisfaction in the ERP implementation in East Java universities. The results of this study show that: 1) the user understands that the ERP system is a routine that should be done and not think about the advantages which has the ability to integrate with other parts of mutual interest, and 2) The rapid development of science and technology, creating a new structure, the global structure. Research by Dezdar (2012) about the relationship between system quality and user satisfaction also found similar with this research's finding.

The test result of the hypothesis toward the dimension of the user key in transformational leadership shows $P$-value $=0.000$. The significant variable in the user key transformational leadership in moderating the influence of the quality system toward the user satisfaction shows that, the higher value of the transformational leadership which is owned by the key user, it will effect greater to the influence of the quality system toward the user satisfaction. The conclusion is that the user key transformational leadership proved to moderate a system quality of variable toward the user satisfaction, this is accordance with the other research that said the higher value of the transformational leadership by the key user, it will effect greater to the influence (Nikolić, Sefić, 2017)

\section{Conclusion, suggestion and limitation}

The universities in East Java, Indonesia in the implementation of the ERP system is already reflecting the level of user satisfaction at a level above the average, as seen from the distribution of scores from the respondents' answer that indicates average value of 3.65 on a scale of 5 , in which it can be considered as good. The universities ERP system implementation in East Java, Indonesia indicates the appropriatness of the analysis with DeLone and McLean model; it suggests that the model appropriatness that is developed to analyze an information system is appropriate.

The need for maximum efforts for universities that have not entered the ranking at Webomatrics, in order to enter in the rating activities so that universities can be trusted their existence by world. The universities should compete globally beacuse one of the strong indicators of the quality of the higher education is the implementation of ERP, so that the investment in ERP must be improved as well. The universities in Indonesia that are in the Webometrics ranking should be increased, because there are more than $75 \%$ of universities have not been in those rating. The need to consider other variables as moderation. In developing countries, the support of top management is one of the important factor in ERP implementation.

\section{References}

Bass, Bernard M. (1990). From transactional to transformational leadership: learning to shahe the vision. organizational dynamics, Vol. 18, pp. 19-31

Bass, Bernard M., and Ronald E. Riggio. (2006). Transformational leadership second edition, New Jersey London: Lowrence Erlbaum Associates Publisher.

Beheshti, H. M.. (2006). What managers should know about ERP/ERP II. Management Research News, Vol. 29, no. 4, pp. 184-193.

Bycio, P., Hackett, R.D., and Allen, J.S. (1995). Further Assessments of Bass's, Conceptualization of Transactional and Transformational Leadership. Journal of Applied Psychology, vol. 80, no. 4, pp. 468-478.

DeLone, McLean. (1992). Information System Success: The Quest for the Dependent Variable. The Institute of Management Sciences, Information System Research, Vol. 3, No. 1, pp. 60-95.

DeLone, McLean. (2003) The DeLone and McLean model of information system success: a ten-year updated. Journal of management information system, vol. 19, no. 4, pp. 9-30.

Ehie, I. C., \& Madsen, M. (2005). Identifying critical issues in enterprise resource planning (ERP) implementation. Computers in Industry, vol. 56, no. 6, pp. 545-557.

Gibson I., and Donnely. (1987). Research areas include organizational behavior and development. Department of Management, Chair of Univ. of Kentucky's. 
Gill, A.,et al. (2010). The Relationship Between Transformational Leadership and Employee Desire for Empowerment, International Journal of Contemporary Hospitality Management, vol. 22, no. 2, pp. 263-273.

Gyampah, Kwasi-Amoako. (2004). ERP Implementation Faktors-A Comparison of Managerial and EndUser Perspectives. Business Process Management Journal, vol. 10, no. 1, pp. 23-32.

Hau TTV, Kuzic J., 2010. Change management strategies for the successful implementation of enterprise resource planning systems. In 2010 Proc. of the IEEE Second Int. Conf. on Knowledge and Syst. Eng., Hanoi, IEEE, Hanoi Vietnam ,October 07-October 09 2010: 178-182.

Khayun and Ractham (2011). Measuring e-Excise Tax Success Factors: Applying the DeLone \& McLean. Information Systems Success Model, Proceedings of the 44th Hawaii International Conference on System Sciences, 1530-1605/11 \$26.00 (C) 2011 IEEE, pp. 1-10.

Kim, dan Lee. (2014). Quality, Perceived Usefulness, User Satisfaction, and Intention to Use: An Empirical study of Ubiquitous Personal Robot Service. Asian Social Science, Vol. 10, No. 11, pp. 1-16

Leon, A., (2005). Enterprise Resources Planning, McGraw-Hill Publishing Company Limited, New Delhi.

Makokha \& Ochieng. (2014). Assessing the success of ICT's from User Perspective: Case study of Coffee Research Foundation Kenya. Journal of Management and Strategy Sciedu Press, Vol. 5, N0. 4, pp. 46-53.

Manchanda and Mukherjee. (2014). An empirical application of DeLone and McLean Model in Evaluating Decision Support system in The banking sector of Oman, Journal of International Technology and information Management. International information management association, inc, Vol. 47-58

Mandal A., Gunasekaran B. (2003). Issues in implementing ERP: A case study Purnendu. European Journal of Operational Research 146, pp. 274-283.

Mason. (1978). Measuring information output: a communication system approach. information and management, vol 1, no. 4, pp. 219-234.

O’Leary, Daniel E. (2000). Enterprise Resource Planning Systems: Systems, Life Cycle, Electronict Commerce, and Risk. United States of America, Cambridge University Press

Premkumar, G., dan King W.R. (1992). An empirical asessesment of information system planning and the role of informations system in organization. Journal of management information system, vol. 9, no. 2, pp. 99-125.

Shannon, C. E., \& Weaver, W. (1949). The mathematical theory of communication. Urbana, Illinois: University of Illinois Press.

Shehab, E.M., Sharp, M.W., Supramaniam, L., and Spedding, T.A. (2007). Enterprise Resource Planning An Integrative Review. Businees Process Management Journal, vol. 10, no. 4, pp. 359-366.

Spathis, C., and Constantinides, S. (2003). The Usefullness of ERP System for effective Management. Industrial Management and Data System Journal, vol. 103, no. 9, pp. 677- 685.

Stone, G.A., Russel, R.F., and Patterson. (2004). Transformational Versus Servant Leadership: A Difference in Leader Focus. The Leadership dan Organization Development Journal, vol. 25, no. 4, pp. 349-361.

Subba, S.R. (2000). Enterprise resource planning: business needs and technologies. industrial management \& data system, vol. 100, no. 2, pp. 71-81.

Taylor, Shirley, and Todd, Peter A. (1995). Understanding Information Technology Usage: A Test of Competing Models. Information System Research, vol. 6, no. 2, pp. 144-176.

Umble, E.J., Haft, R.R., Umble, M.M. (2003). Enterprise Resources Planning: Implementation Procedures and Critical Success Faktors. Europen Journal of Operation Research, vol. 146, no. 1, pp. 241 257.

Urbach, Smolnik \& Riempp. (2010). An empirical investigation of employee portal success. Journal of Strategic Information Systems, Institute of Research on Information Systems (IRIS), EBS Universität für Wirtschaft und Recht, Rheingaustraße 1, 65375 Oestrich-Winkel, Germany, Vol. 19, pp. 184-206.

Wallace dan Kremzar. (2001). ERP: Making It Happen, The Implementers' Guide to Success with Enterprise Resource Planning, John Wiley \& son, inc, Newyork.

Wei, K. S., Loong, A. C., Leong, Y. M., \& Ooi, K. B. (2009). Measuring ERP system success: a respecification of the Delone and McLean's IS success model. Paper presented at the Symposium on Progress in Information and Communication Technology (SPICT'09), Kuala Lumpur, Malaysia. 